\title{
A PRELIMINARY STUDY ON BEES (HEMENOPTERA: APOIDEA: APIFORMES) FROM NORTHERN AND NORTH CENTRAL VIETNAM
}

\author{
Khuat Dang Long*, Le Xuan Hue, Dang Thi Hoa, Pham Huy Phong \\ Institute of Ecology and Biological Resources, VAST, *khuatdanglong@iebr.ac.vn
}

\begin{abstract}
For the first time, a list of tropical bee species found in Northern and North Central Vietnam is provided. This list includes 59 bee species in 21 genera belonging to 5 families. Bees were collected in protected areas, i.e. national parks and nature reserves in 2011-2012 during the spring-summer and summer-autumn seasons. At high elevations exceeding $300 \mathrm{~m}$ a.s.l., bee abundance was dominated by bumble bee species, such as Bombus magrettii and B. trifasciatus, and two honey bees Apis laboriosa and A. dorsata were occurred in forest and moutain areas. In abandoned orchards and fruit gardens close to forest fragments, bee abundance was dominated by Xylocopa species. In Northern and North Central Vietnam, deforested areas or cultivated lowlands were dominated by several bees having widespread distribution, namely native honey bee Apis cerana subspecies indica mainly of bred colonies, blue banded bees Amegilla albigena, A. zonata, leafcutter bee Megachile fulvovestila and carpenter bee Xylocopa tranquebararorum. In this paper notes on conservation status of bee, their behaviour and distribution are also discussed.
\end{abstract}

Keywords: Hymenoptera, Apoidea, Apiformes, species diversity, Northern, North Central Vietnam.

\section{INTRODUCTION}

Bees (Hymenoptera: Apoidea) are considered as important beneficial insects because they provide direct products, such as, honey, royal jelly and wax, as in the case of honey bees or stingless bees $[14,17]$. More importantly, the indirect benefit of bees comes from their role as critical pollinators for both wild and cultivated plants $[7,9,12]$. In many cases, plants depend on specialist bees for their cross-pollination (reproduction) and vice versa some oligolectic bees depend on specific plants for their survival. Approximately $75 \%$ of global food crops are dependent on pollinators for production [6]. The remaining non-pollinator dependent food crops may still benefit from pollinators by improving fruit quality, weight and/or the number of seeds [2, 10-12].

Wild bees are diverse in nature, however, deforestation and intensification of cultivated land has decreased food sources and available nesting sites [5, 15]. The magnitude of how important wild bee pollination to crop production and wild plant communities is unknown. With the decline of managed honey bee colonies [16], the study of wild bee pollination has become increasingly important. Currently, information on Vietnamese bee diversity and their conservation status is poorly documented; our paper is the first to report on the diversity of bees in Northern and North Central Vietnam. This study fills an improtant gap in the knowledge of Vietnamese bee fauna and this preliminary list will also serve as a foundation for potential further taxonomic, ecological, diversity or comparative studies.

\section{MATERIALS AND METHODS}

Bee specimens for this list were collected from various surveys conducted in Northeast, Northwest and Central Vietnam, which encompasses North Central Vietnam (fig. 1). A total of more than 700 bee specimens were collected during the surveying period (20112012). Based on the analysis of collected bee specimens and available literatures $[1,3,4,18]$, the first two authors of this paper completed bee identifications for this list.

Material was collected using a sweep net and malaise traps. Quantitative samples were then taken and counted. Most bees were either caught mainly in open habitats close to forest fragments or near protected areas. Other sites types that bees were found in include openings, clearings, roadsides, forester's lodges, forest edges, afforested lands, abandoned orchards, 
and fruit gardens in agricultural lands or suburban zones.

Terminology used in this paper follows Michener (2007) [8], all photos were taken using Canon G15 digital camera and for the specimens checking was made using an Olympus SZ40 binocular microscope. The defenition of bee conservation status was made by using all observations on bee abundance and encounters categorized as frequent/common, moderate/occasional or rare.
Explanations and abbreviations of areas and localities are as follows: NE. Northeast; NW. Northwest; NC. North Central; C. Central; RRD. Red River Delta; HB. Hoa Binh province (Thuong Tien Nature Reserve); PT. Phu Tho (Xuan Son NP); VP. Vinh Phuc (Tam Dao National Park); BG. Bac Giang; HN. Hanoi; HT. Ha Tinh (Vu Quang NP); QB. Quang Binh (Phong Nha-Ke Bang NP) and TT-Hue (Thua Thien-Hue, Bach Ma NP), and Northern Vietnam incudes Northeast, Northwest and Red River Delta (table 1).

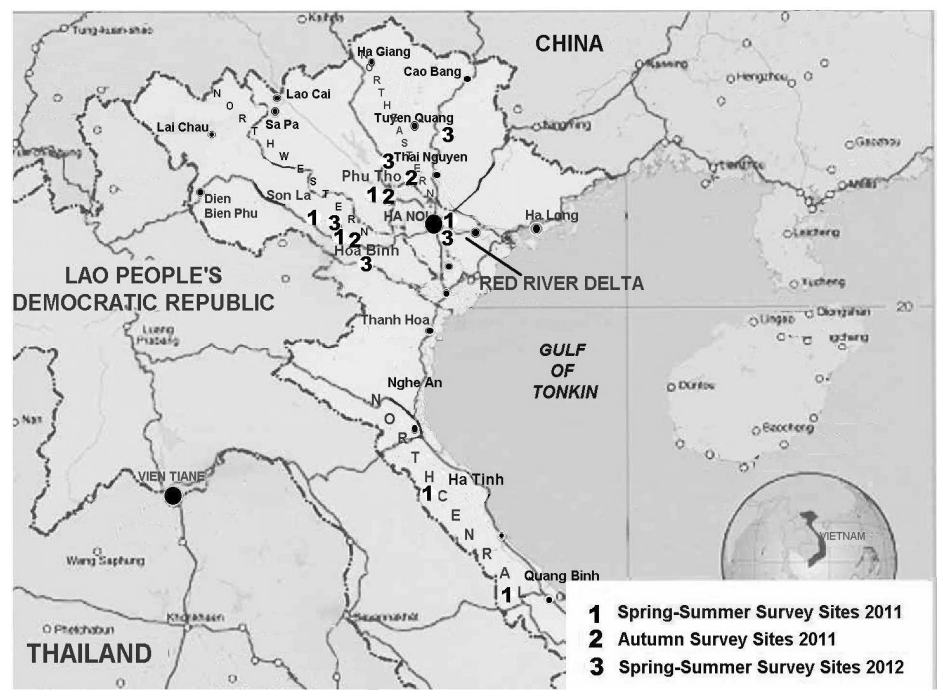

Figure 1. Map of research sites

\section{RESULTS AND DISCUSSION}

\section{Species composition structure}

More than 700 collected bees from north and north central Vietnam are members of 59 bee species in 21 genera belonging to 5 families (table 1). Of the total, the family Apidae comprises 35 species (59.3\%), Megachilidae 13 $(22.0 \%)$, Halictidae 9 (15.3\%), each of two families Collectidae and Mellichidae has one species $(3.4 \%)$. The maximal number of bees occurred in Northwest, Northeast, Red River Delta and North Central is 30,13 16 and 6, respectively. In combining our data with an additional 60 bee records previously collected and reported by Le Xuan Hue (2008) [3], there were 32 additional species records of bees (table 1).

\section{Habitat requirement and bee behaviour}

Additional observations that were carried out in spring-summer and autumn surveys (2011), which showed that most bees of the genera Apis, Bombus and Xylocopa were more active in the morning, between the hours of 7:00 to 10:00 a.m. These bees were less active in the afternoon, with the exception of Apis cerana of bred colonies, that are active whole day. In the Northern and North Central Vietnam, in early Spring and late Autumn, bee species prefer actively visiting pollen-rich flowers, probably because they need more pollen for nest building, and most bee species are concentrated on nectar-rich flowers because in throughout Spring and Autumn, in these seasons the bees need more food for breeding, for example, the native honey bee Apis cerana could be observed in common fruit trees as longan Dimocarpus longan, litchi Litchi chinensis, mango 
Mangifera indica, Dracontomelum duprereanum, while Apis laboriosa preferably visiting flowers of wild plants, such as Rhodomyrtus tomentosa, Melastoma spp., that are mainly found in secondary forests; the concentration of blue banded bee species as Amegilla albigena and A. zonata was observed on flowers of Solanum album and several plants of the family Fabaceae, such as soybeans Glycine soja, green peas Vigna radiata, Vigna unguiculata; bumble bee species as Bombus triasciatus and B. magrettii could be observed on flowers of several plants of the family Cucurbitaceae, such as cucumber Cucumis sativus, loopah Luffa cylindrica, pumpkin Cucumis pepo, chayote Sechium edule and flowers of wild plants as Melastoma spp.; carpenter bee species Xylocopa tumida was often preferably visiting flowers of Luffa cylindrica. Consequently, reforestation sites and their adjacent abandoned orchards appear to have relatively higher bee abundance compared to other sites we visited.

It was observed that protected areas were beneficial for bee communities as they provide suitable nesting and foraging places. Surely that orchards or agricultural areas adjacent to these protected areas then provided nectar sources for these bee communities.

\section{Preliminary notes on conservation status and distribution}

A relatively higher abundance of honey bees, Apis cerana (subspecies indica) and $A$. laboriosa was observed at most sites compared to A. mellifera and A. dorsata (table 1). The native honey bee Apis cerana indica was observed in large numbers foraging in concentrated areas where there were blooms of the monoculture plants (cultural or wild), while Apis laboriosa were only observed in wild habitats. Bumble bee species, Bombus spp. were rarely observed in either reforestation areas or adjacent orchards with only very few individuals encountered in each site type. Among carpenter bee species, Xylocopa tranquebarorum has a widespread distribution that the species is frequently occurred in cultivated areas of all the research sites, while the rest are often occured in abandoned orchards close to forest but infrequently caught in lowland habitats, except one species, X. tumida, that frequently occured in gardens in the lowlands.

Surely enough that two blue banded bee species as $A$. albigena and $A$. zonata have a widespread distribution, the two species are common and frequently encountered in different habitats in Red River Delta and Northeast Vietnam. The representatives of beepollinations, which can be more commonly observed in the wild were showed in figure 2 .

The honey bee subspecies Apis cerana cerana is known to have a limited distribution and is considered rare. We encountered this subspecies in the high limestone mountainous area, viz. Dong Van karst plateau Geopark. The native honey bee Apis cerana subspecies indica is common and abundant in Northeast, Northwest and North Central Vietnam, this is probably because $A$. cerana indica is commonly bred and maintained by local indigenous people for their subsidary income. Meanwhile the wild colony of Apis cerana indica is rarely found in nature with the exception of a few small nests observed in mountainous forests in Northwest and Northeast Vietnam. The honey bee species Apis laboriosa was frequetly caught in Northwest, Northeast and North Central Vietnam, while Apis dorsata was recorded in North Central only and another honey bee Apis florea was rarely observed in either Northern or Central Vietnam and is considered rare in these areas.

Four bumble bee species, Bombus campestris, B. fulnerarius, B. magrettii and $B$. trifasciatus were frequently encountered at high elevation sites exceeding $300 \mathrm{~m}$ a.s.l. in Northwest and Northeast Vietnam, of those Bombus trifasciatus and B. funerarius were found mainly in the Northwest while Bombus campestris and B. magrettii were found mainly in the Northeast (table 1). This is believed that Bombus bees prefer habitats close to forests at high altitute to habitats in the lowlands, that convinced the moutainous forests and their vicinity areas have the special value and play 
an important role for the conservation of bumble bees.

Among small carpenter bee species, two species Ceratina hieroglyphica and $C$. picta were frequently encountered in all research sites of Northwest, Northeast and North Central Vietnam, while Ceratina viridissima was observed in the North Central only. Similarly, Tetralonia himalayensis is a common species occurred in all the research areas while Eucera chinensis and Tetralonia duvaucelli were occasionally encountered in Northeast and Northwest Vietnam but not in North Central, and Tetralonia mitsukurii was rarely encountered in Northwest Vietnam only.

All the remaining bee species reported were encountered with a moderate rate in any one of four survey areas. Additionally, it must be noted that the longer time of surveys conducted in the north is reason why the number of bees recorded in Northeast and Northwest Vietnam higher than that in North Central Vietnam.

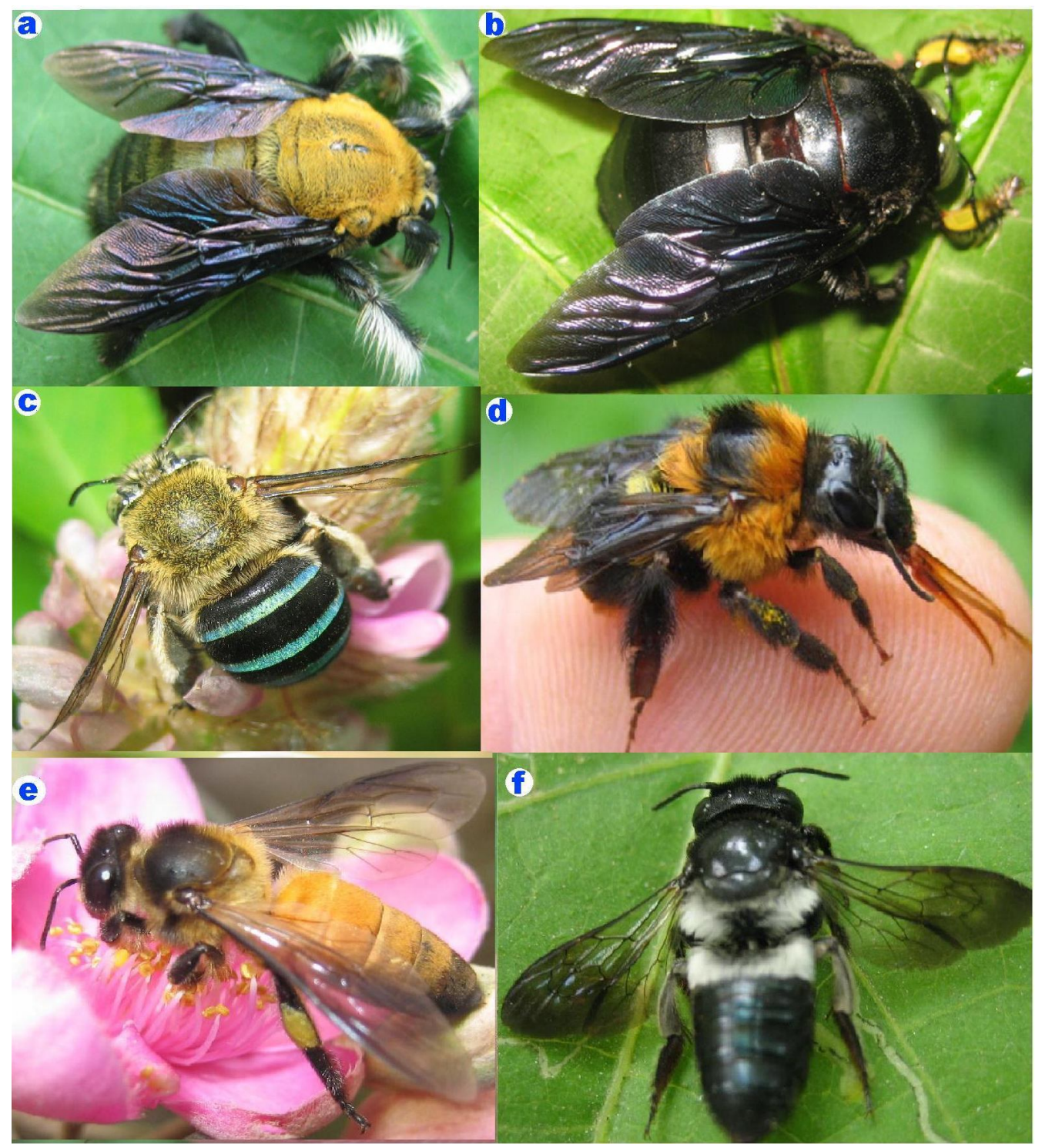

Figure 2. Bee species commonly observed in Northern and North Central Vietnam a. Xylocopa aestuans; b. Xylocopa latipes (male); c. Amegilla zonata; d. Bombus trifasciatus; e. Apis laboriosa and f. Megachile conjuncta 
Table 1. List and distribution of 21 genera and 59 species of the superfamily Apoidea in Norhteast, Northwest and North Central Vietnam

\begin{tabular}{|c|c|c|c|c|c|c|c|c|}
\hline \multirow{3}{*}{ Taxon } & \multicolumn{8}{|c|}{ Distribution } \\
\hline & \multicolumn{2}{|c|}{ NW } & \multicolumn{2}{|c|}{$\mathrm{NE}$} & \multirow{2}{*}{$\frac{\text { RRD }}{\mathrm{HN}}$} & \multicolumn{2}{|c|}{$\mathrm{NC}$} & \multirow{2}{*}{$\begin{array}{c}\text { C } \\
\text { TT- } \\
\text { Hue }\end{array}$} \\
\hline & $\mathrm{HB}$ & PT & BG & VP & & HT & QB & \\
\hline \multicolumn{9}{|l|}{ Apidae: Apinae } \\
\hline \multicolumn{9}{|l|}{ Anthophorini (Blue banded bees) } \\
\hline 1. Amegilla albigena Lepeletier & 2 & & 1 & & 9 & & & \\
\hline 2. Amegilla confusa (Smith) & & 2 & & & & & & \\
\hline 3. Amegilla comberi (Cockerell) & 2 & 1 & 4 & & & & & \\
\hline 4. Amegilla zonata Linnaeus & 12 & 5 & 4 & 1 & 4 & & & \\
\hline \multicolumn{9}{|l|}{ Anthophorini (Mining bees) } \\
\hline $\begin{array}{l}\text { 5.* Anthophora acervorum } \\
\text { villoceta } \text { Smith }\end{array}$ & & 1 & & & & & & \\
\hline $\begin{array}{l}\text { 6. Anthophora quadrifasciata } \\
\text { (Villers) }\end{array}$ & & 1 & & & & & & \\
\hline $\begin{array}{l}\text { 7. Anthophora quadrimaculata } \\
\text { (Panzer) }\end{array}$ & & 2 & & & & & & \\
\hline \multicolumn{9}{|l|}{ Apini (Honey bees) } \\
\hline $\begin{array}{l}\text { 8. } \dagger \text { Apis cerana indica Fabricius } \\
\dagger \uparrow \text { Apis cerana indica } \text { Fabricius }\end{array}$ & $\begin{array}{l}++ \\
+\end{array}$ & + & + & + & + & + & + & + \\
\hline 9. Apis dorsata Fabricius & & & & & & 5 & & \\
\hline 10. Apis laboriosa Smith & 2 & & 2 & & & 2 & 6 & 1 \\
\hline 11.**Apis mellifera Linnaeus & & 2 & & & & & & \\
\hline \multicolumn{9}{|l|}{ Bombini (Bumble (Garden) bees) } \\
\hline $\begin{array}{l}\text { 12. Bombus (Psithyrus) campestris } \\
\text { Panzer }\end{array}$ & & & & 4 & & & & \\
\hline 13. Bombus funerarius Smith & 6 & & & & & & & \\
\hline 14. Bombus magretti Griboro & & & 3 & 9 & & & & \\
\hline 15. Bombus trifasciatus Smith & 34 & 7 & & & & & & \\
\hline \multicolumn{9}{|l|}{ Eucerini (Uncommon name bees) } \\
\hline 16. Eucera chinensis Smith & 9 & 40 & & 1 & 5 & & & \\
\hline 17. Tetralonia duvaucelii Lepeletier & 2 & 3 & & 2 & 1 & & & \\
\hline $\begin{array}{l}\text { 18. Tetralonia himalayensis } \\
\text { Bingham }\end{array}$ & 16 & 21 & 1 & 3 & & & & 1 \\
\hline $\begin{array}{l}\text { 19. Tetraloniella mitsukurii } \\
\text { Cockerell }\end{array}$ & 1 & & & & & & & \\
\hline \multicolumn{9}{|l|}{ Melectini (Cuckoo bees) } \\
\hline 20. Thyreus histrio Fabricius & & 1 & & & & & & \\
\hline \multicolumn{9}{|c|}{ Xylocopinae: Ceratinini (Small carpenter bees) } \\
\hline 21. Ceratina hieroglyphica Smith & 2 & 5 & 3 & & & & & 2 \\
\hline 22. Ceratina picta Smith & 4 & & & & & & 1 & \\
\hline 23. ${ }^{*}$ Ceratina viridissima (Guero) & & & & & & & & 1 \\
\hline \multicolumn{9}{|l|}{ Xylocopini (Carpenter bees) } \\
\hline 24. Xylocopa aestuans Linnaeus & 9 & 1 & & & & & & \\
\hline 25. Xylocopa basalis Smith & 1 & & 2 & & & & & \\
\hline
\end{tabular}




\begin{tabular}{|c|c|c|c|c|c|c|c|c|}
\hline 26. Xylocopa bryorum Fabricius & 1 & & & & & & & \\
\hline 27. Xylocopa collaris & 1 & & & & & & 1 & \\
\hline 28. ${ }^{*}$ Xylocopa dejeanii Lepelitier & & & & & & & 1 & \\
\hline 29. Xylocopa latipes (Drury) & 3 & & & & & & & \\
\hline 30. Xylocopa rufipes Smith & & 1 & & & & & & \\
\hline 31. Xylocopa nasalis Westwood & 1 & & & & & & & \\
\hline 32. Xylocopa shelfordi Cameron & 1 & & & & & & & \\
\hline 33. Xylocopa tenuiscapa Westwood & 1 & & & 1 & & & & \\
\hline $\begin{array}{l}\text { 34. Xylocopa tranquebarorum } \\
\text { (Swederus) }\end{array}$ & 7 & 2 & 1 & & 4 & & & \\
\hline 35. Xylocopa tumida Friese & & & & & 9 & & & \\
\hline \multicolumn{9}{|l|}{ Colletidae } \\
\hline 36. Hylaeus floralis Smith & & & & & & & & 1 \\
\hline \multicolumn{9}{|l|}{ Megachilidae (Leafcutter bees) } \\
\hline 37. Anthidiellum rasorium Smith & & 2 & & & & & & \\
\hline 38. Anthidiellum sp. & & & 1 & & & & & \\
\hline 39. Euaspis basalis Ritsema & & 1 & & & & & & \\
\hline 40. Megachile anthracina Smith & 1 & & & & & & & \\
\hline 41. Megachile ardens Smith & & & & & 1 & & & \\
\hline 42. Megachile bellula Bingham & 1 & & & & 1 & & & \\
\hline 43. Megachile conjuncta Smith & & 3 & & & 1 & & & \\
\hline 44. Megachile disjuncta (Fabricius) & & & & & 5 & & & \\
\hline 45. Megachile fulvovestita Smith & 2 & & 2 & & 3 & & & \\
\hline 46. Megachile spissula Cockerell & & & & 2 & & & & \\
\hline 47. Heriades $\mathrm{sp}$. & 1 & & & & & & & \\
\hline 48. Megachile sp. & & 1 & & & & & & \\
\hline 49. Trachusa sp. & 1 & & & & & & & \\
\hline \multicolumn{9}{|l|}{ Melittidae (Melittid bees) } \\
\hline 50. Melitta montana $\mathrm{Wu}$ & & & & 1 & & & & \\
\hline \multicolumn{9}{|c|}{ Halictidae: Nomiinae (Small solitaty bees) } \\
\hline 51. Lipotriches antennata Smith & & & & & 1 & & & \\
\hline 52. Lipotriches fulvinerva $\mathrm{Wu}$ & 1 & & & & & & & \\
\hline 53. Nomia chalybeata Smith & & 2 & & 2 & 14 & & & \\
\hline 54. Nomia curvipes Fabricius & & 1 & & & & & & \\
\hline 55. Nomia formosa Smith & 1 & & & & 1 & & & \\
\hline 56. Nomia fuscipennis Smith & & 2 & & & & & & \\
\hline 57. Nomia terminata Smith & 1 & & & 1 & & & & \\
\hline 58. Lipotriches sp. & & & & 1 & & & & \\
\hline 59. Nomiodes sp. & & & & & 3 & & & \\
\hline Total of species occurred & 30 & 24 & 12 & 13 & 16 & 3 & 5 & 6 \\
\hline
\end{tabular}

( ${ }^{*}$. not found in the list of bees recorded in 2008 [3] for the bee fauna of Vietnam; $\left({ }^{* *}\right)$. introduced species; $(\dagger)$. wild bee colony and $(\dagger \dagger)$. bred bees.

Acknowledgements: This paper is a result of the project received the financial support from the Nagao Natural Environment Foundation 2011-2013. Thanks are due to Dr. Packer Laurence and MSc. Ngo Thu Hien, York University, Toronto, Canada for correction of English text and comments on the manuscript. 


\section{REFERENCE}

1. Bingham C. T., 1897. The Fauna of British India including Ceylon and Burma. LondonBerlin, 1: 408-564.

2. Free J. B., 1993. Insect Pollination of Crops. $2^{\text {nd }}$ Edition, Academic Press, NY. 684 pp.

3. Le Xuan Hue, 2008. Diversity of bee superfamily (Hym.: Apoidea) from Vietnam, Proceedings of the $6^{\text {th }}$ Vietnam National Conference on Entomology, Agriculture publishing house, H.: 934-937 (in Vietnamese, summary in English).

4. Le Xuan Hue, 2010. Disscovery of a new species of the genus Bombus Latreille, 1802 (Hymenoptera: Apidae) from Vietnam. TAP CHI SINH HOC, 32(2): 21-23.

5. Khuat Dang Long, Nguyen Thi Phuong Lien, Pham Thi Nhi, 2004. A Survey of Beneficial Hymenopteran bees and wasps, their use value in the buffer zone of Cuc Phuong National park (North Vietnam), SYLVATROP: 14(1-2): 67-94.

6. Klein A. M., Vaissière B., Cane J. H., Steffan-Dewenter I., Cunningham S. A., Kremen C. and T. Tscharntke, 2007. Importance of crop pollinators in changing landscapes for world crops. Proceedings of the Royal Society of London: Series B. Biological Sciences, 274: 303-313.

7. McGregor S. E., 1976. Insect Pollination of Cultivated Crop Plants. USDA AGRIC. Handbook 496. 411 pp.

8. Michener C. D., 2007. The Bees of the World. 2nd Ed. Johns Hopkins University Press, Baltimore, MD. xvi+[1]+953 pp.

9. Ollerton J., Winfree R. and S. Tarrant, 2011. How many flowering plants are pollinated by animals?. Oikos, 120(3): 321-326.
10. Raw A. and J. B. Free, 1977. The pollination of coffee (Coffea arabica) by honeybees. Tropical Agriculture, 54: 365371.

11. Reddy A. G. S., Raju K. V. V. S. N. and P. S. Dharmaraj, 1988. Pollination in cultivars of Coffea arabica L. Journal of Coffee Research, 18: 78-84.

12. Roubik D. W., 1995. Pollination of Cultivated Plants in the Tropics. FAO Agric. Serv. Bull., 118. 198 pp.

13. Roubik D. W., 2002. The value of bees to the coffee harvest. Nature, 417: 708.

14. Souza B., Roubik D. W., Barth O., Heard T., Enríquez E., Carvalho C., Villas-Bôas J., Marchini L., Locatelli J., Persano-Oddo L., Almeida-Muradian L., Bogdanov S. and P. Vit., 2006. Composition of stingless bee honey: setting quality standards. Interciencia, 31(12): 867-875.

15. Nguyen Huu Thao, Khuat Dang Long, Nguyen Thi Phuong Lien, Pham Thi Nhi, 2011. A preliminary assessment of diversity and conservation value of two hymenopteran groups in buffer zone of Xuan Son National Park, Proceedings of the $7^{\text {th }}$ Vietnam National Conference on Entomology, Agriculture publishing house, H.: 302-309) (in Vietnamese, summary in English).

16. Watanabe M. E., 1994. Pollination worries rise as honey bees declines. Science, 265(5176): 1170.

17. Winston M. L., 1991. The biology of the honey bee. Cambridge, MA: Harvard University Press.

18. Wu Y., 2000. Fauna Sinica Insecta, Beijing, vol. 20,412 pp. 


\title{
BƯỚC ĐẦU NGHIÊN CÚU CÁC LOÀI ONG MẠTT (HEMENOPTERA: APOIDEA: APIFORMES) Ở MIỀN BẮC VÀ BĂC TRUNG BỘ VIỆT NAM
}

\author{
Khuất Đăng Long, Lê Xuân Huệ, Đặng Thị Hoa, Phạm Huy Phong
}

Viện Sinh thái và Tài nguyên sinh vật

\section{TÓM TÁT}

Bài báo bước đầu đưa ra danh sách 59 loài của 21 giống và 5 họ thuộc tổng họ ong mật Apoidea, trong số đó, họ ong mật Apidae có 35 loài (chiếm 59,3\%), họ Megachilidae: 13 loài (22,0\%), họ Halictidae có 9 loài $(15,3 \%)$, hai họ còn lại Collectidae và Mellichidae mỗi họ chỉ có 1 loài $(3,4 \%)$. So sánh với danh sách 60 loài ong mật được thống kê gần đây nhất cho khu hệ ong mật ở Việt Nam, có 32 loài lần đầu được ghi nhận cho khu hệ ong mật của Việt Nam.

Hầu hết các loài ong mật thường chỉ xuất hiện ở các sinh cảnh rừng hoặc vườn gần rừng, tuy nhiên, chúng chiếm ưu thế ở sinh cảnh rừng tự nhiên và rừng trồng, một số loài gặp ở sinh cảnh khác như vườn bỏ hoang hoặc vườn cây ăn quả gần rừng. Điều này chứng tỏ sinh cảnh tự nhiên có giá trị đặc biệt và ý nghĩa quan trọng trong việc bảo tồn các loài thuộc họ ong mật. Một số loài ong có phân bố rộng thường gặp ở cả vùng đồng bằng và vùng núi như Amegilla albigena, A. zonata, Megachile fulvovestila, Xylocopa tranquebararorum, riêng loài ong mật Apis cerana phân loài indica xuất hiện ở tất cả các sinh cảnh do điều kiện được nuôi trong các hộ gia đình, còn quần thể hoang dã của phân loài này rất ít gặp trong tự nhiên.

Các loài thuộc hai giống Apis và Bombus chỉ thấy xuất hiện ở rừng tự nhiên hoặc rừng trồng ở khu vực vùng núi, đó là quần thể các loài ong hoang dã Apis cerana phân loài indica, A. dorsata, A. laboriosa. Ở vùng Tây Bắc, Đông Bắc và Bắc Trung bộ, chúng tôi chưa bắt gặp phân loài ong mật Apis cerana cerana và loài $A$. florea. Bốn loài ong thuộc giống Bombus mới chỉ bắt gặp ở sinh cảnh rừng hoặc vườn cây gần rừng ở độ cao trên $300 \mathrm{~m}$, đây là giống có phân bố hẹp theo sinh cảnh với các đai độ cao nhất định.

Tù khóa: Hymenoptera, Apoidea, Apiformes, đa dạng loài, ong mật, Việt Nam.

Ngày nhận bài: 12-8-2012 